by persons ${ }^{37}$ who aided in drafting the Amendment of 1951 support this conclusion and indicate that the "notwithstanding" clause refers to the predecessor statutes which barred assignment of claims against the government. ${ }^{38}$

In view of the foregoing, it is submitted that the well-settled rule establishing the superiority of the surety's right over that of the assignee should be controlling, ${ }^{39}$ and that the decision of the Court of Claims in Royal Indemnity Co. v. United States ${ }^{40}$ is eminently proper. The purpose of the Act of 1940, as amended, is to modify the protection formerly accorded to the government. The Act was not otherwise intended to inure to the benefit of private parties or to affect their relations inter sese. ${ }^{4 \mathrm{I}}$

\title{
PROOF OF NON-CONFORMITY IN SALES CASES
}

This note states the present law on the burden of proof of non-conformity in sales cases as it appears in several factual situations. It compares the usual test for allocating this burden with one based on opportunity for inspection and cites the operation of the Perishable Agricultural Commodities Act ${ }^{1}$ in conjunction with the Uniform Sales Act in order to indicate that while the latter Act does not preclude the use of third party inspection to determine the facts quickly and avoid litigation, it does not provide, as does the Uniform Commercial Code, for agreement that the findings of such inspection shall be binding in any subsequent litigation or adjustment.

As a general rule, the party pleading affirmatively has the burden of proof. ${ }^{2}$ That is, such party has what may be called the risk of non-production of evidence, and also, the risk of non-persuasion. ${ }^{3}$ Thus the seller suing for price, absent acceptance, under Section $63^{4}$ of the Uniform Sales Act or for damages

${ }^{37}$ Kupfer, op. cit. supra note 3.

${ }^{38}$ Op. cit. supra note 2.

${ }^{39}$ Prairie State Bank v. United States, 164 U.S. 227 (1896).

4093 F. Supp. 891 (Ct. Cl., 1950).

11 Authorities cited note 14 supra.

1 Perishable Agricultural Commodities Act of 1930, 46 Stat. 531 (1930), as amended, 7 U.S.C.A. $\$ \$ 499$ et seq. (1939).

2 Three forms of this rule are: (1) "The burden of proof is upon the party asserting the affrmative of the issue, using the latter term in the larger sense and as including any negative proposition which such party might have to show." (2) "It means only that each party must establish his own case." (3) "[It] depends entirely on whether the claim . . . made by the defendant, is or is not an affirmative defense." Morgan and Maguire, Cases and Materials on Evidence 55 ( $3 d$ ed., 1951).

3 For an analysis of these terms, see ibid., at 47.

4 Uniform Sales Act $\$ 63$. Before the Uniform Sales Act, a seller could sue for the price on the buyer's wrongful refusal to accept the goods, even before the property in them had passed, in the majority of American jurisdictions. However, B. J. Shelton v. Theo Muckle Engineering Co., 121 Colo. 509, 218 P. 2d 1057 (1950) is noted in 99 Pa. L. Rev. 109, at 110 (1950) as 
for non-acceptance under Section 64 of the Uniform Sales Act ${ }^{5}$ must prove that the goods conformed to the contract specifications. ${ }^{6}$ Likewise, where the buyer

follows: "[The] instant case must be taken as the first square holding that the doctrine of election applies to $\$ \S 63$ and 64 of the Sales Act."

The distinction between an action for the price and one for damages is said to be that a suit for the price implies a passage of title, while a suit for damages is based on breach of contract. But title is not a unitary concept. Title passes against the seller when the goods are appropriated to the contract; it does not pass against the buyer unless the goods conform or, if non-conforming, the buyer accepts them. Llewellyn, Through Title to Contract and a Bit Beyond, 15 N.Y.U.L.Q. Rev. 159 (1938).

The Uniform Commercial Code avoids the anomalies produced by the title concept. Section 2-709 (1) provides that title need not pass in order to allow suit for the price, as follows:

"When the buyer fails to pay the price as it becomes due the seller may recover together with any incidental damages under the next section, the price

"(a) of goods accepted or of conforming goods lost or damaged after risk of their loss has passed to the buyer; and

"(b) of goods identified to the contract if the seller is unable after reasonable effort to resell them at a reasonable price or the circumstances reasonably indicate that such effort will be unavailing."

Further, if the price action fails, recovery for damages may be had in the same action. Ibid., at 2-709 (3). Finally, any doctrine of election of remedies is explicitly rejected. Ibid., at 2-703 (1).

It is worth noting that the Uniform Sales Act $\S 60$ gives the seller a right of resale if the goods are perishable or such right is reserved. And under Section 61 of the Uniform Sales Act, a seller with a right of lien, or having stopped the goods in transit, may have a right to rescind, where the right to do so on default has been reserved. Here, again, the Uniform Commercial Code makes resale the seller's chief remedy, thereby discouraging suits for price or damages. Uniform Commercial Code $\S 2-706$.

${ }^{5}$ Uniform Sales Act $\S 64$. Except where Section 63 applies, i.e., where title has passed, Section 64 of the Uniform Sales Act is the seller's chief remedy where the buyer wrongfully refuses payment.

- Central Wisconsin Supply Co. v. Johnston Bros. Clay Works, 194 Ia. 1126, 190 N.W. 961 (1922), was a suit by a Wisconsin wholesale coal dealer against an Iowa clay products manufacturer for the price of coal delivered and refused, and for the prepaid freight. The price quoted permitted "any advance in price at mines." Because of a strike, there was an addition to this quoted price, and it appears that this advance was the cause of the buyer's rejection. The agent of the carrier at destination testified as to the bills of lading, freight bills and receipts; and the plaintiff's treasurer testified as to such information as he derived from the mining company.

The defendant moved for a directed verdict on the ground that the plaintiff's evidence was insufficient to show performance. The court said, at 1131, 963: "That the order was made and defendant did refuse to receive or pay for the coal sent is admitted, but to entitle plaintiff to recover it has the burden of showing a full, complete, and substantial performance of the contract on its part." The court noted that if this were done, the plaintiff could sue for the contract price, or sell the coal and recover the loss or damage, and continued: "It is not a simple general order for 'coal' or 'Harrisburg' coal, or 'lump' coal, but for 'two-inch Harrisburg, Ill., lump coal.' . . . We think it very clear that the record entirely fails in proof of that fact. Not a single witness undertakes to say from his own observation what was the character, kind or quality of this coal. Not a record or document or bill of lading describes it as Harrisburg, Ill., two-inch lump coal. . . . [The bill of lading does refer to 'lump coal.'] The plaintiff's objection that the defendant did not offer any specific objection to the kind or quality of the coal misses the real point. To make a prima facie case as against defendant's denial the burden is on plaintiff, as we have already pointed out, to make affirmative showing of its own performance or tender of performance, and until then the question whether defendants had a valid reason for refusing to receive the coal is immaterial." 
pleads affirmatively in suing for breach of warranty under any of the subsections of Section 69 of the Uniform Sales Act, ${ }^{7}$ he must prove the non-conformity. ${ }^{8}$

The common sense of such a rule is severely tested in the situation where the goods are completely destroyed while in transit. Where the seller sues for the price, it is reasonable that he should have to prove the conformity, ${ }^{9}$ since only

7 Uniform Sales Act $\S 69$. Recoupment, acceptance and damages, rejection and damages if the goods have not passed, and rescission are the remedies afforded the buyer on breach of warranty. As contrasted with the seller's remedies, the election doctrine is explicit. Ibid., at 69 (2). However, Friedman v. Swift \& Co., 18 F. Supp. 596 (S.D.N.Y., 1937), indicates the possibility that a buyer may rescind and still obtain damages for negligence.

The Uniform Commercial Code resolves the election problem by permitting revocation as to acceptance, while preserving the right to damages. Thus Section 2-711 of the Code provides:

"(1) Where the seller fails to make delivery or repudiates or the buyer rightfully rejects or justifiably revokes acceptance then with respect to any goods involved, and with respect to the whole if the breach goes to the whole contract (Section 2-612), the buyer may cancel and whether or not he has done so may in addition to recovering so much of the price as has been paid

"(a) 'cover' and have damages under the next section as to all the goods affected whether or not they have been identified to the contract; or

"(b) recover damages for non-delivery as provided in this Article (Section 2-713)."

The Uniform Sales Act provides for damages for non-delivery in Section 67.

Section 2-711 (3) of the Uniform Commercial Code makes resale a major remedy of the buyer (as contrasted with Section 69(5) of the Uniform Sales Act) comparable to that of the seller under Section 2-706 of the Code:

"On rightful rejection or justifiable revocation of acceptance a buyer who has paid all or part of the price has a security interest in goods in his possession or control for the amount paid plus any expenses reasonably incurred in their inspection, receipt, transportation, care and custody and may on notifying the seller of his intention to do so hold such goods and resell them in like manner as an aggrieved seller (Section 2-706)."

${ }^{8}$ Santa Rosa-Vallejo Tan. Co. v. C. Kronauer \& Co., 228 mll. App. 236, 247 (1923). In an action for price of harness leather sold under trade name, delivered to defendant-buyer and rejected as of inferior quality, the court stated: "That as a general rule the burden of proof is on the plaintiff to establish his case by a preponderance of the evidence is elementary and scarcely requires the citation of authorities. . . It is, however, also true that when under the pleadings it appears that a defendant relies upon an affirmative defense ... the burden of establishing such affirmative defense is upon the defendant who asserts it. ... The defense of defendant here was necessarily based on section 69 of the Sales Act. ... The defense which it so sought to introduce was an affirmative one. The plaintiff established a prima facie case by undisputed evidence, and ... therefore... the burden of proof to establish the defense pleaded was upon the defendant."

'Levy v. Radkay, 233 Mass. 29, 31, 123 N.E. 97, 98 (1919). In suit by the seller for the price of "goods" sold by samples shown at the buyer's store, the court said: "The evidence warranted a finding that the plaintiff selected and packed the goods as ordered and delivered them for transmission to the defendant to Mahoney's Express, the carrier or bailee named by the defendant for that purpose. St. 1908, c. 237, pt. 2, sec. 19, rule 4 (2). The goods were destroyed by fire while in the possession of Mahoney's Express." (Emphasis added.)

But cf. Kinney v. Horwitz, 93 Conn. 211, 105 Atl. 438 (1919). In this case, a carload of potatoes was destroyed by fire after arrival. The contract was for one carload of potatoes delivered at New Haven. By custom, this meant draft against seller's order bill of lading, payable on arrival. The potatoes arrived February 4 th. On February 5 th, the buyer had notice of the arrival and the draft was presented. The buyer did not act, and on the 13th the potatoes were destroyed by fire. The time for inspection was held to be 48 hours after notice of arrival. (Inspection was also provided for in the bill of lading, which read: "To the order of H. E. 
he has seen the goods. What does not seem reasonable is that in suit by the buyer for the return of the purchase price, where goods have been so destroyed, the seller should avoid such burden.10

Where the buyer has accepted the goods or as a result of delay in rejection is held to have accepted them under Section 48 of the Uniform Sales Act, the burden of proof of non-conformity is on him. "In effect, he has given his sanction to the goods, so that their quality is not in issue unless he chooses to affirmatively

Kinney, New Haven, Conn. Notify Newark Produce Company, New Haven, Conn. Inspection allowed.") The "property" had passed, under Section 19 (5) of the Uniform Sales Act. The seller sued for the price of the carload of potatoes. On the question of proving conformity, the court at 218, 440 simply said: "The defendant did not inspect, but no claim is made on this ground or that the potatoes were not of the kind and quantity required by the contract. The plaintiff had therefore performed his part of the contract fully. . . The plaintiff, upon proof of delivery .... and no objection taken to the kind or quality or condition of the potatoes, need not show acceptance to make the sale complete."

${ }^{10}$ Glanzer v. J. K. Armsby Co., 100 Misc. 476, 165 N.Y.S. 1006 (S. Ct., 1917). In this case, the plaintiff-buyer had paid the price to defendant-seller, on presentation of a draft with bill of lading endorsed in blank attached. In an action to recover this amount from the seller, because the "Fava" beans which were the subject of the contract had been seized and destroyed by federal inspector as being "buggy," the court, per Lehman, J., stated: "[T] he seller fully complied with its contract if it delivered to the carrier goods in accordance with its contract; ... the general property to these goods passed to the buyer upon such delivery, subject only to the seller's right to possession as security for payment, and the goods were thereafter at the risk of the buyer. Since in this case the plaintiffs must show failure of consideration for the payment made to the defendant, they have the burden of proving that the goods delivered to the carrier were not in accordance with the contract of sale. In the absence of such proof, it was error to direct a verdict in favor of plaintiffs." Tbid., at 481, 1009. This opinion reversed a verdict for the plaintiffs based on the fact that "[D]efendant unsuccessfully attempted to introduce evidence to establish certain affirmative defenses." Tbid., at 479, 1008.

11 Cudahy Packing Co. v. United States, 75 F. Supp. 239 (Ct. Cl., 1948) was a case in which plaintiff-seller sought to recover the purchase price of eggs which the Government, as buyer, had rejected after inspection. The court recapitulated the relevant provisions of the Uniform Sales Act, and stated: "Section 48 provides ... that 'the buyer is deemed to have accepted the goods ... when, after the lapse of a reasonable time, he retains the goods without intimating to the seller that he has rejected them.' And Section 69, in providing for the remedies of a buyer for breach of warranty, states that 'where the goods have been delivered to the buyer, he cannot rescind the sale if he knew of the breach of warranty when he accepted the goods, or if he fails to notify the seller within a reasonable time of the election to rescind.' ... In the circumstances of this case [a perishable commodity, obviously intended for current consumption by the troops at Camp Forrest] we think the merit of plaintiff's claim is to be judged by this statutory rule and we conclude, both as a fact and as a matter of law, that defendant retained the 2,786 dozen eggs beyond a reasonable time without intimating to plaintiff that it had rejected them." Ibid., at 241. "When the property in the goods is deemed to have passed to the buyer in accordance with the applicable provisions of the Uniform Sales Act, and the buyer wrongfully neglects or refuses to pay for the goods according to the terms of the contract or the sale, under section 63 of the Act, the seller may maintain an action against him for the price of the goods." Ibid., at 244.

This being the case, questions as to conformity could only arise under Section 69 of the Uniform Sales Act, in which event the burden of proof is on the buyer. See authority cited note 8 supra. Thus Foley \& Co. v. Excelsior Stove \& Mfg. Co., 265 Ill. App. 78, 96 (1932) states, in holding that the burden of proof of the non-conformity of printed catalogues was on the buyer where the seller sued for price. "INlor can acceptance be considered an excuse or 
plead non-conformity. However, when the seller does not deliver goods which conform to the contract, so that the buyer does not wish to accept them because of such non-conformity, mechanical application of the rule that the burden of proof is on the party pleading affirmatively ${ }^{12}$ is again inequitable. The buyer, in an action for non-delivery, should not be made to prove non-conformity where he has given no indication of assent to the character of the goods, since the seller will know best in what manner he provided goods to meet the terms of the contract.

In the situation where the buyer has refused to accept goods which are perishable, expensive to keep or fluctuating in value and has sold them on behalf of a seller who has failed to remove them after notice of non-conformity, the rule requiring the seller to prove conformity as the party pleading affirmatively again disregards realities. ${ }^{13}$ The seller cannot get at the goods to prove compliance with the contract terms. Further, the buyer has more knowledge of the specific characteristics on which he may choose to rely than does the seller.

A test which is more consonant with the facts is required to determine the incidence of burden of proof in sales cases. Such a test would place the burden of proof on the party who in actuality is more capable of sustaining it, because of

waiver of nonperformance. The theory of acceptance is that it constitutes an admission of performance such as dispenses with proof thereof."

Uniform Commercial Code $\$ 2-607$ (3), Comment 6 (Spring Draft, 1950) indicates that the Code restates the present law on burden of proof where the buyer has accepted the goods:

"The last sentence of subsection (3) unambiguously places the burden of proof to establish breach on the buyer after acceptance."

Similarly, just as Section 69 of the Uniform Sales Act proscribes rescission in the event of acceptance which is the consequence of unreasonable delay in notice of election to rescind, so Sections 2-606 and 2-608 of the Uniform Commercial Code reach the same result in this situation as to "revocation."

12 Gilmore v. Mulvihill, 109 Mont. 601, 98 P. 2 d 335 (1940). The plaintiff-buyer, suing for return of purchase price and damages for non-delivery of 285 five year old ewes, testified that he had personally examined 30 of a lot of 310 from which he was to select his complement and had found them to be more than five years old. The court at 611-12, 340 approved the following instruction which had been given by the trial court: "You are instructed that if you find from a preponderance of the evidence that the defendants agreed to sell to the plaintiff 285 head of five-year-old ewes, and that defendants did not deliver or offer to deliver to the said plaintiff the said 285 head of five-year-old ewes so agreed to be sold to plaintiff, then and in that event your verdict should be for the plaintiff and against the defendants for the sum of $\$ 285$, paid by the plaintiff to the defendants at the time of the making of the agreement for purchase of said sheep ... and in addition thereto you should also allow plaintiff such damages as he has proven by the evidence to have sustained by reason of the failure of the defendants to sell and deliver to him the sheep so agreed to be sold." (Emphasis added.)

13 Descalzi Fruit Co. v. Sweet \& Son, Inc., 30 R.I. 320, 323, 75 A. 308, 311 (1910) (peaches). "In the absence of the plaintifs, unrepresented, the defendant having knowledge of the existing conditions, and having the goods cast upon it in this emergency, not only had the right to protect itself from the freight charges, but also to prevent the owners from needlessly sacrificing their goods without benefit, and at a total loss to themselves, with additional freight charges, through ignorance and obstinacy." (Emphasis added.) 
facts and circumstances peculiarly within his knowledge. ${ }^{14}$ In the situation where the goods are completely destroyed while in transit, the seller alone will know the facts about conformity. Where the seller delivers goods which do not conform to the contract and the buyer has not impliedly approved them by acceptance, the seller by virtue of experience in fulfilling the terms of the contract will be better able to sustain the burden of proof in an action for non-delivery. But where the buyer has refused to accept the goods and has sold them justifiably on behalf of the seller, the facts on conformity are then peculiarly within the knowledge of the buyer.

A realistic rule, such as that suggested, would place the burden of proof of conformity on the seller in the situations where the goods are lost in transit or have not been delivered in conformity with the contract absent acceptance, and on the buyer where the buyer has sold the goods justifiably on behalf of the seller.

The general rule on burden of proof is changed radically when a negotiable bill of lading is involved. Here the burden is entirely on the buyer. To make a prima facie case for price or damages, the seller need only present the documents and prove their genuineness. ${ }^{16}$ The buyer in the situations where such a bill of lading is used will generally wish to negotiate the bill before the arrival of the goods themselves. If the seller were required to prove conformity, the buyer

14 Morgan and Maguire, Cases and Materials on Evidence 55-56 n. 6 (3d ed., 1951). After discussing the three forms of burden cited in note 2 supra, the authors state: "The court did not consider a fourth test which is sometimes relied upon, namely, that the burden rests upon the party who is best able to sustain it because the facts and circumstances are peculiarly within his knowledge. This is most frequently resorted to where a negative is to be proved. See Bradshaw v. Hilton Lumber Co., 172 N.C. 219, 90 S.E. 146 (1916). See as to the defense of license, 9 Wig. $\$ 2486$, note 3." Accord: Anthony v. American Express Co., 188 N.C. 407, 124 S.E. 753 (1924).

15 " [I]f the buyer can show that the documents are fraudulent or that the goods are not of the proper quality, he can set up these facts as a defense or counterclaim to any action brought by the seller. In other words, the burden of proof rests on the buyer." Finkelstein, Legal Aspects of Commercial Letters of Credit 225 (1930). "The seller presents his documents and rests his case. In order to put the documents in evidence, he must, of course, introduce prima facie proof that they are genuine. That, however, is the extent of his obligation. The buyer, if he desires to avoid a finding against him, must either offer rebutting evidence to the effect that the documents are forged, that they are fraudulent, or that the goods are of inferior quality. Practically, this means that the buyer must show reasonable grounds for not paying under the terms of the contract." Ibid., at 225 n. 5.

Carriage of Goods by Sea Act, 49 Stat. 1208, 1209 (1936), 46 U.S.C.A. $\$ 1303$ (4) (1944), states:

"Such a bill of lading shall be prima facie evidence of the receipt by the carrier of the goods as therein described."

Uniform Commercial Code $\$ 1-202$ states:

"A document in due form purporting to be a bill of lading, policy or certificate of insurance, official weigher's or inspector's certificate, consular invoice, or any other document authorized or required by the contract to be issued by a third party shall be prima facie evidence of its own authenticity and genuineness and of the facts stated in the document by the third party." 
would be obtaining a right of inspection which the instrument is designed to avoid.

The issuance of a letter of credit does not change the incidence of the burden of proof as it exists under the c.i.f. or other negotiable bill of lading situation. However, in the pure documentary situation, the buyer can "defend or counterclaim to any action brought by the seller" that the goods are not of the proper quality, even though in general he has no right to refuse payment until such time as he has had an opportunity for inspection..$^{16}$ To make such a defense or counterclaim, where for example the seller sues for the price in the event that "the buyer takes the bill of lading but fails to remit the price or accept the bill of exchange,"17 the buyer must have grounds for believing the goods to be defective. He cannot refuse to pay simply because he does not know they are not defective. ${ }^{18}$ In the letter of credit situation, on the other hand, the majority rule

${ }^{16}$ Authority cited note 14 supra.

"It is submitted that the general rule to be laid down is that where the buyer knows or has reasonable grounds for believing the goods to be defective, he may refuse to accept and pay for the documents and nevertheless recover damages from the seller if the goods on arrival actually prove to be defective. Where such refusal is arbitrary, he cannot recover, though goods are defective, and though he cannot be held obligated to perform, as he cannot be deemed to have been ready and willing to perform." Finkelstein, Legal Aspects of Commercial Letters of Credit 227 n. 11 (1930).

Section 2-512 of the Uniform Commercial Code states:

"(1) Where the contract requires payment before inspection non-conformity of the goods does not excuse the buyer from so making payment unless

"(a) the non-conformity appears without inspection; or

"(b) despite tender of the required documents the circumstances would excuse a financing agency under the provisions of this Act (Section 5-120)."

Uniform Commercial Code $\$ 2-512$ (1) (a), Comment 3 (Spring draft, 1950) states:

"Clause (a) of this subsection states an exception to the general rule based on common sense and normal commercial practice. The apparent non-conformity referred to is one which is evident in the mere process of taking delivery."

The formulation of the exception to the rule in Finkelstein apparently extends to situations including and other than those where "the apparent non-conformity ... is one which is evident in the mere process of taking delivery."

17 '[When] the buyer takes the bill of lading but fails to remit the price or accept the bill of exchange ... he has the power to pass the title to a bona fide purchaser. . . However, the problem is little more than academic today when shippers take bills in their own names and send them to their agents for presentation to the buyer, or deliver the documents to a bank in which a confirmed letter of credit has been established by the buyer." Proposed "Warsaw Rules, 1928," Relating to Contracts C.I.F., 29 Col. L. Rev. 813, 819 (1929).

"Nor should it be lost sight of that cash against bill of lading (with or without prior inspection) is a type of transaction found chiefly in the case of agricultural produce moving to a central market, and almost not at all in the case of manufactured commodities moving from a central distributing point toward the consumer. Automobiles are an exception notable for its uniqueness. And documentary practices of the c.i.f. sort are still limited largely to overseas trade." Llewellyn, Introduction to Finkelstein, Legal Aspects of Commercial Letters of Credit xviii (1930).

18 '"T]he buyer must pay even though the goods have not as yet arrived and though he does not know whether or not they are the goods he desires." Finkelstein, Legal Aspects of Commercial Letters of Credit 178 (1930). "It is submitted, however, that if the buyer knows some- 
is that even though there are grounds for believing the goods to be non-conforming, the non-conformity will not be a defense to a bank in any suit by the seller. ${ }^{19}$

The salient feature of the negotiable bill of lading situation and the analytically identical letter of credit situation is that the seller is to be paid on presentation of the documents regardless of opportunity for inspection. It is this feature ${ }^{20}$ which accounts for an allocation of the burden of proof which is inconsistent with the test of "facts peculiarly within the knowledge of one party." It must be noted, however, that although inspection is inconsistent with quick resale by means of the bill of lading, it is the buyer who intends to resell the goods. Therefore, an explanation of the unusual distribution of the burden of proof in this documentary situation which relies merely on the existence of an intent to deny the right of inspection is misleading. It is more likely that placing the burden of proof on the buyer is intended to benefit the seller by reducing his credit risk, to the extent that buyers will normally pay on presentation of the documents rather than shoulder the burden of proof before knowing the facts on conformity. It has been suggested elsewhere that there is no reason why the seller should not tender to the buyer a certificate of inspection. ${ }^{21}$ In view of the foregoing discussion, such a practice would be unacceptable to sellers. Moreover,

thing is wrong with the goods ... he can set [up such facts] as a defense or as a counterclaim to an action by the seller." Tbid., at 179 n. 8 . Cf. Uniform Sales Act $\$ \$ 47,49$.

${ }^{19}$ Finkelstein, Legal Aspects of Commercial Letters of Credit 233 (1930): "From these cases, the general proposition may be laid down that the bank has not the power to set up as a defense an honest difference of opinion between buyer and seller as to quality, quantity, price, or any other element of the sales contract, provided the documents are in order, all other terms of the letter of credit fulfilled, and no question of fraud is involved, unless there be a specific provision in the letter of credit giving the bank such a privilege."

This rule puts the burden of litigation on the buyer, hence, practically, the burden of proof.

Uniform Commercial Code \$2-325 (3) states:

'Unless otherwise agreed the term 'letter of credit' or 'banker's credit' in a contract for sale means an irrevocable credit available by its terms not only to the seller but also to a good faith purchaser of drafts drawn under it which is issued by a financing agency of good repute and, where the shipment is overseas, of good international repute."

20 "The seeming inequity of these results disappears when one considers the business usages under which c.i.f. contracts are made. Most of the contracts are used in connection with the import and export trade. The importer is very seldom the ultimate consumer. Generally, he does not even sell to the retail merchants. In the majority of instances, the goods go to some wholesale commission merchant. Frequently, the whole amount is disposed of to one party. In any event, the importer has, in most cases, resold the goods before they have arrived, particularly if they are coming from a distant port. In order to dispose of the mercbandise in this manner, he must have documents which show what the goods are and which demonstrate the fact that he has control over them. If the documents are in proper form, they do show these facts, and the buyer is properly made to pay against them." Finkelstein, Legal Aspects of Commercial Letters of Credit 179 (1930).

It would seem that the buyer is both cajoled and beaten under this rationale.

${ }^{21}$ Statutory Commodity Standards, 31 Col. L. Rev. 872 n. 3 (1931): "The documentary contract presents one situation in which [the problem of obtaining assurance that the goods will conform and that if they do they will be accepted] is peculiarly pressing. ... But there is no reason why the buyer in this ["blindfold" payment] situation should not be given a certificate showing that the goods conformed when put on the car[s]." 
if sellers can exact such concessions as the loss of inspection rights, there is no reason to believe they would accede to it. Current practice with respect to inspection certificates must determine whether legal sanctions should be invoked to compel their use.

It is possible under present law to utilize the opportunity for inspection to determine the facts on conformity quickly. The operation of the Perishable Agricultural Commodities Act ${ }^{22}$ in conjunction with the Uniform Sales Act indicates that such determination may avoid costly litigation, thereby promoting quick disposition of the goods.

The buyer, for example, may call the Inspection Division which has been set up under the Act in his city, ${ }^{23}$ concerning a carload of peaches. The inspector on duty examines the peaches to determine the percentage of peaches of each type called for. The contract will often specify a "few," "some," or "mostly," and the Inspection Division can translate these terms into given percentages standardized by usage. The inspector then determines whether the percentage of deterioration for each type of peach is permissible in view of the usual deterioration for peaches transported a comparable distance. The inspector may then give an opinion on whether the buyer can "reasonably" 24 reject. In the great majority of cases, the opinion of the inspector will end the matter. This would also be true if it is the seller who calls for inspection to determine whether the buyer's rejection is reasonable.

The practicability of this machinery depends on the existence of standard commodity grades and quantity terms which are recognizable by the inspector, as well as on a background of decisions under the Secretary of Agriculture as to what is permissible deterioration under a given set of circumstances.

There are two other techniques available under the Perishable Agricultural Commodities Act which fall short of actual litigation. These are the informal and the formal arbitration. They will follow the filing of a complaint by one of the parties who does not accept the opinion of the inspector. That is, the seller may insist that the goods conformed, or the buyer may reject despite the opinion of the inspector.

The parties may choose either the formal or the informal arbitration at this

226 Stat. 531 (1930), as amended, 7 U.S.C.A. $\$ 499$ et seq. (1939). "The Perishable Agricultural Commodities Act was passed in 1930 to curb unfair and fraudulent practices prevalent in the marketing of perishable products. Dealers would often reject shipments or demand allowances on the price on the basis of fabricated claims of unmerchantability. Because of the difficulties of proof and the expenses of long distance suits, sellers often took no action. Congress, by this act, set up the machinery to remedy these abuses." Buyer's Liability After Rejecting "Rolling Acceptance Final"' Shipment 16 Univ. Chi. L. Rev. 584 n. 3 (1949). See 71 Cong. Rec. 2162-69, 2195-2204 (1929); 72 Cong. Rec. 8537-57 (1930).

${ }^{23}$ Department Interpretation and Construction of Perishable Agricultural Commodities Act, Service and Regulatory Announcements, No. 121 (Rev. May, 1943) states federal inspection is available for perishable commodities which are the subject of dispute.

24 'Tllustrations of reasonable cause for rejection are failure to deliver produce bought or sold, or contracted to be bought, sold or consigned, or a material breach of contract by the other party, operation of law, or a condition beyond ... control." Ibid. 
stage..$^{25}$ The formal arbitration requires the presence of both parties in Washington for a hearing under the Secretary of Agriculture. The informal arbitration is a decision of the local Perishable Agricultural Commodities Office based on information obtained from both parties, including inspection certificates of the seller. The informal decision may then be appealed to the Secretary of Agriculture for a formal hearing. ${ }^{26}$ The formal decision in its turn may also be appealed to a United States District Court, thereupon reaching the actual trial stage.

The procedures under the Perishable Agricultural Commodities Act show that the opportunity for inspection can be utilized to avoid litigation. But it should be possible to utilize this opportunity for inspection to obtain arbitration awards and inspection certificates which will satisy the burden of proof in the event of litigation. Allocation of the burden of proof on the basis of opportunity for inspection would otherwise be of little avail.

In the instance of arbitration under the Perishable Agricultural Commodities Act, the findings of fact on conformity by formal arbitration under the Secretary of Agriculture will be prima facie evidence in the United States District Court. ${ }^{27}$ Thus, although enforcement under the Perishable Agricultural Commodities Act is effective because of provision in the Act for withdrawal of licenses of dealers who do not make reparation as ordered, ${ }^{28}$ such findings on conformity may be overruled in the United States District Court. ${ }^{29}$ The logic of this may be that here the provision for arbitration is unilateral.

There appears to have been doubt at first as to the validity of private, as opposed to federal, arbitration. ${ }^{30}$ Thus the New York Arbitration Law expressly rendered valid contracts to arbitrate future disputes. ${ }^{31}$ Even today, it

s Ibid. $\quad{ }^{25} \mathrm{Ibid}$.

2746 Stat. 531 (1930), as amended, 7 U.S.C.A. $\S 499$ et seq. (1939).

${ }^{28}$ Department Interpretation and Construction of Perishable Agricultural Commodities Act, Service and Regulatory Announcements, No. 121 (Rev. May, 1943).

29 Fletcher v. Ozark Packing Co., 188 F. 2d 858 (C.A. 8th, 1951) overruled a finding by the Secretary of Agriculture that the seller had complied with shipping requirements as evidenced by condition on arrival and mode of packing.

so "At common law, specific performance would not be granted of an agreement to arbitrate, nor of an award when made. Hopkins v. Gilman, 22 Wis. 476 (1868). This is also true of the English Arbitration Act, but there is effective negative procedure for the enforcement of the agreement, because the party seeking to enforce may secure a stay of an action brought in derogation of the arbitration agreement. ... It is not true of the New York statute, and a few others... Nominal damages only could be secured for breach of the agreement to arbitrate at common law; but substantial damages for failure to live up to the award. See Hopkins v. Gilman, supra. The latest tendency is to consider the award as almost equivalent to a court judgment for certain purposes. M. P. Sloan \& Co. v. Standard Chemical \& Oil Co., 256 Fed. 451 (C.C.A. 5th, 1918)." Proposed "Warsaw Rules, 1928" Relating to Contracts C.I.F., 29 Col. Rev. 813, 828 n. 173 (1929).

31 "Adoption of the New York Arbitration Law in 1920 ... gave statutory approval to agreements providing for arbitration of future disputes and enabled the participants to enforce awards in summary proceedings if made under the conditions specified by the law." Blunt, The Story of an Arbitration Workshop, 3 Arb. J. 299, 302 (1939). 
appears that although association rules provide for mandatory arbitration under such a statute, it is still best to make very specific stipulation for arbitration in the original contract of sale. ${ }^{32}$

But although contracts providing for private arbitration had previously been against public policy, they are now encouraged and rendered binding upon the parties both as a matter of policy and of statute. ${ }^{33}$ The situation may differ in the absence of statutory authorization..$^{34}$

It has been said that there is no apparent reason why contracts to arbitrate made after a dispute has arisen should not be binding. ${ }^{35}$ Even though such con-

${ }^{32}$ Mere reference to association rules providing for such arbitration may be insufficient. Ibid., at 303.

${ }^{33}$ See, for an incisive discussion of this development, Freezing Issues of Fact Under a New Uniform Sales Act, 41 Col. L. Rev. 494, 502 n. 64 (1941) and cases therein cited.

34 However, even where such awards in ex parte arbitration are not judicially upheld, as in Illinois, they may have practical value. Thus, the Chicago office of the American Arbitration Association reports agreements to arbitrate are widely employed. Sanctions would include reporting refusal to abide by the clause to the Chamber of Commerce, and the fact that both parties bave an interest in settling the dispute. Often, the desire to preserve mutually advantageous commercial relationships will be present. The Association's standard arbitration clause states:

"Any controversy or claim arising out of or relating to this contract, or the breach thereof, shall be settled by arbitration in accordance with the Rules of the American Arbitration Association, and judgment upon the award rendered by the Arbitrator(s) may be entered in any Court having jurisdiction thereof." Commercial Arbitration Rules, American Arbitration Association, as amended and in effect Jan. 1, 1952.

Selection of arbitrators proceeds "in the following manner: Immediately after the filing of the Submission or copy of a Demand ... the Tribunal Clerk shall submit simultaneously to each party to the dispute, an identical list of names of persons chosen from the Panels. Each party to the dispute shall have seven days from the date of the mailing of such lists in which to examine said lists, cross off any names to which he objects and number the remaining names indicating the order of his preference, and return the list to the Tribunal Clerk. ... From among the persons who have been approved on both lists, and in accordance with the designated order of mutual preference if any, the Tribunal Clerk shall invite the acceptance of an Arbitrator to serve." Ibid., at 2.

"The following states honor the clause [providing, by contract, that future disputes will be settled by arbitration]: Arizona, California, Connecticut, Louisiana, Massachusetts, Michigan (where the clause must be signed separately), New Hampshire, New Jersey, New York, Ohio, Oregon, Pennsylvania, Rhode Island (where the clause must be the last one directly above the signature), Washington and Wisconsin."' 3 Operations Report, Research Institute of America, No. 21 (Oct. 11, 1949).

In Illinois (where the clause is not honored), utilization of the Association's techniques has not been realized as fully with respect to commodities as it has in other areas. However, individual commodity associations may have comparable provisions and methods for arbitration. As examples, the American Fruit and Vegetable Shippers Ass'n as jobbers may arbitrate with the Carlot Dealers Ass'n, as a result of previous association agreements. Similar practice pertains with respect to potatoes in the Carlot Potato Ass'n. Here the technique permits each association one arbitrator of its own choosing, after which these representatives of the jobbers and carlot associations respectively choose a third arbitrator upon whom both agree. (Information obtained from statement by officers of associations referred to.)

${ }^{35}$ "While there would seem to be no objection to agreeing to the 'survey' after the dispute has arisen, it would seem desirable to provide for it in the original contract or sale." Op. cit. supra note 33, at $501 \mathrm{n} .60$ (1941). The difficulties referred to are those mentioned note 32 supra. 
tracts are generally enforced, the new Uniform Commercial Code ${ }^{36}$ provides for arbitration after dispute has arisen, thus obviating any possible doubt as to whether courts will uphold such agreements.

Inspection itself may be the subject of contract. Thus, where there is a permissive state statute, the parties may contract for such inspection with the result that the findings as to grade and condition will be irrebuttable. ${ }^{37}$ If there is no contract for inspection, the statutes provide that the findings will be prima facie evidence of grade and condition. ${ }^{38}$ The statutes either adopt federal grades or determine their own standards. ${ }^{39}$ However, some state statutes make state findings either conclusive or presumptive evidence of the facts in dispute. ${ }^{40}$

The new Uniform Commercial Code ${ }^{41}$ appears to provide useful solutions for several remaining doubts:

In furtherance of the adjustment of any claim or dispute

(a) either party on reasonable notification to the other and for the purpose of ascertaining the facts and preserving evidence has the right to inspect, test and sample the goods including such of them as may be in possession or control of the other; and

(b) the parties may agree to a third party inspection or survey to determine the conformity or condition of the goods and may agree that the findings shall be binding upon them in any subsequent litigation or adjustment.

${ }^{35}$ Uniform Commercial Code § 2-515. "Preserving Evidence of Goods in Dispute."

${ }^{37}$ Fed. Grain Co. v. Hayes Grain and Commission Co., 161 Ark. 51, 255 S.W. 307 (1923). See Ark. Stat. Ann. (1947) §77-506.

38 "A certificate when not superseded by a finding on appeal of the grade, classification, quality or condition of any agricultural product, issued under this act . . . and all certificates issued under the authority of the Congress of the United States relating to grade, classification, quality or condition of agricultural products shall be accepted in any court of this State as prima facie evidence of that grade, classification, quality or condition of such agricultural product at the time of its inspection." Ark. Stat. Ann. (1947) § 77-508.

39 "The Board is authorized to fix and promulgate as the official standard for this State for any agricultural product or container, the standard for such product or container which may have been promulgated or announced therefor under the authority of the Congress of the United States, and in carrying out the provisions of this act . . . the Chief Inspector is authorized to cooperate with the United States or any department thereof in accomplishing the matters and things provided for herein." Ark. Stat. Ann. (1947) \$ 77-505.

Well defined standards seem an essential factor to certificates of inspection which will show that the goods conform to the contract.

${ }^{40}$ See Statutory Commodity Standards, 31 Col. L. Rev. 872, 874 and instances of such statutes therein cited.

41 Uniform Commercial Code $\$ 2-515$, Cómment 3 (Spring draft, 1951) states:

"Paragraph (b) ... suggests the use of arbitration, where desired, of any points left open. Where any question arises as to the extent of the parties' agreement under the paragraph, the presumption should be that it was meant to extend only to the relation between the contract description and the goods as delivered, since that is what a craftsman in the trade would normally be expected to report upon. Finally, a written and authenticated report of inspection or tests by a third party, whether or not sampling has been practicable, is entitled to be admitted as evidence under this Act, for it is a third party document." 
If the parties do not agree to third party inspection, the provision for inspection of goods in the control of the adverse party may be helpful. Further, the provision makes explicit the right to agree after the dispute to third party inspection, leaving the provision for binding effect optional in view of arbitration proceedings which may not be as flexible if fact findings are binding.

Another useful feature of the Section is its provision for testing "in furtherance" of adjustment of a dispute. This seems to permit necessary testing while avoiding the hazard of acceptance as a result of such testing which exists under the Uniform Sales Act.

However, one question remains. Should not the Section stipulate that third party inspection is compulsory and that the results of such inspection are binding, with respect at least to perishable agricultural commodities? This is a device already adopted in some states, with reference to such commodities. ${ }^{42}$ The fact that permissive language as used in the Section avoids the necessity of special drafting for specific products does not mitigate the difficulties of those situations where disposition of perishable commodities for whom it may concern is delayed as a consequence of dispute about conformity.

In summary, it may be said that the availability of arbitration and third party inspection of binding or prima facie effect means that the party with an opportunity to inspect goods will be able to utilize inspection so as to sustain the burden of proof of conformity. Therefore, a rule on burden of proof based on opportunity for inspection not only avoids giving the burden of proof to the party with little or no means of sustaining it, but also makes it probable that the party who will have to prove conformity can get the facts necessary to his case, in usable form. Thus, where goods have been lost in transit; where the buyer has refused to accept goods as non-conforming and brings an action against the seller for non-delivery; or where the buyer has sold the goods justifiably on behalf of the seller-in all cases except the bill of lading case which is controlled by special commercial needs, the difficulties of proof deriving from lack of opportunity for inspection or determination of the facts will be fairly met by a rule which places the burden of proof on the party who in actuality does have such opportunity.

12 "From and after the effective date of this subdivision no person, firm, corporation or other organization shall pack for sale, offer for sale, consign for sale or sell in straight or mixed quantities of 1,000 pounds or more in weight the following named fruits and vegetables: Any peaches, cantaloupes, honeydew melons, honeyball melons, watermelons, head lettuce, broccoli, cauliflower, green peas, potatoes, onions and cabbage or spinach grown within the state of Colorado, unless such fruits and/or vegetables conform with the minimum grades or classifications as specified hereinafter in this subdivision, and with such additional grades, grading rules and regulations applicable thereto as may have theretofore been promulgated by the director under the provisions of this subdivision, and unless such fruits and/or vegetables have been inspected as provided in this subdivision. Such inspections as specified and required in this subdivision shall be optional as to apples and pears." Col. Stat. Ann. (1935) c. 69884 . 